\title{
PATIENT PERSPECTIVES ON FAMILY PARTICIPATION IN THE TREATMENT OF HYPERTENSION ${ }^{1}$
}

\author{
Mayckel da Silva Barreto², Sonia Silva Marcon ${ }^{3}$
}

\footnotetext{
${ }^{1}$ Extract from the dissertation "Não adesão à terapêutica medicamentosa em indivíduos com hipertensão arterial em Maringá - Paraná", submitted to the Graduate Program in Nursing at the State University of Maringá, 2012.

${ }^{2}$ Master's degree, Nursing. Assistant Professor, Department of Nursing, State University of Maringá, and School of Phylosophy, Sciences and Languages of Mandaguari. Paraná, Brazil. Email: mayckelbar@gmail.com

${ }^{3}$ Ph.D. Nursing. Associate Professor, Department of Nursing, State University of Maringá. Paraná, Brazil. Email: soniasilva. marcon@gmail.com
}

\begin{abstract}
This study aimed to understand how patients with hypertension perceive their family's influence on adherence and/ or non-adherence to treatment. This descriptive, qualitative research was carried out in the city of Maringá, in the Brazilian state of Paraná. Data were collected at the homes of 18 respondents through semi-structured interviews, during January and February 2012. The respondents' statements were submitted to thematic content analysis. The findings showed that for some patients, the family was a facilitating agent of adherence to treatment by encouraging self-care practices. When families were not perceived as such, it was because the patients felt responsible for self-control of the disease. It was observed that stressful situations reduced self-care practices, and many patients did not receive family support to the degree that they wanted. The study concludes that some participants regarded the family to be a facilitator of adherence to the treatment of hypertension; however, others lacked family support.
\end{abstract}

DESCRIPTORS: Hypertension. Family relationships. Therapy. Social network. Nursing.

\section{PARTICIPAÇÃO FAMILIAR NO TRATAMENTO DA HIPERTENSÃO ARTERIAL NA PERSPECTIVA DO DOENTE}

RESUMO: Neste estudo teve-se por objetivo compreender de que modo as pessoas com hipertensão arterial percebem a influência da família na adesão/não adesão ao tratamento. Pesquisa descritiva, de natureza qualitativa, realizada em Maringá - PR. Os dados foram coletados no domicílio de 18 indivíduos, em entrevista semiestruturada, durante os meses de janeiro e fevereiro de 2012. Os depoimentos foram submetidos à análise de conteúdo, modalidade temática. Com os achados apreendeu-se que, para algumas pessoas, a família foi o agente facilitador da adesão ao tratamento, ao incentivar as práticas de autocuidado. Quando tal situação não ocorria era porque os indivíduos se sentiam responsáveis pelo autocontrole da doença. Observou-se que a vivência de situações estressoras reduzia a prática do autocuidado e muitos não recebiam apoio familiar na proporção desejada. Conclui-se que alguns participantes deste estudo consideravam a família como facilitadora para a adesão ao tratamento da hipertensão arterial, contudo, outros careciam de apoio familiar.

DESCRITORES: Hipertensão. Relações familiares. Terapêutica. Rede social. Enfermagem.

\section{PARTICIPACIÓN FAMILIAR EN EL TRATAMIENTO DE LA HIPERTENSIÓN ARTERIAL EN LA PERSPECTIVA DE LO ENFERMO}

RESUMEN: Este estudio tuvo por objetivo comprender cómo las personas con hipertensión perciben la influencia de la familia en la adhesión/no adhesión al tratamiento. Estudio descriptivo, cualitativo realizado en Maringá-PR, Brasil. Los datos fueron recolectados en el domicilio de 18 individuos, por medio de entrevista abierta, durante los meses de enero y febrero de 2012. Los relatos fueron sometidos al análisis de contenido del tipo temático. Con los hallazgos se evidenció que la familia fue descrita como agente facilitador de la adhesión al tratamiento y estimuladora de la adopción de prácticas de autocuidado y cuando tal situación no ocurría era porque los individuos se sentían responsables por el control de la enfermedad. Se observó aun que muchos participantes no recibían apoyo familiar en la proporción deseada. Se concluye que los participantes en el estudio consideran a la familia como importante para la adherencia al tratamiento de la hipertensión, pero otros carecen de apoyo familiar.

DESCRIPTORES: Hipertensión. Relaciones familiares. Terapéutica. Red social. Enfermería. 


\section{INTRODUCTION}

Recently, the family has been discussed in different fields and social contexts. In health care, work with the family has become one of the most discussed and significantly studied intervention strategies in science and academia, ${ }^{1}$ which has contributed to greater understanding of family experiences in situations of injury and disease, and therefore to more effective functioning of health care services.

As a result of important changes in the incidence and prevalence of diseases and major causes of death, Brazilian families increasingly live with at least one member with chronic disease and its accompanying complications and consequences. ${ }^{2}$ Thus, it is important to understand family participation in coping with chronic diseases (CD) such as systemic arterial hypertension (SAH), and how this participation affects treatment adherence. This is because among CDs, $\mathrm{SAH}$ is a major risk factor for development of renal complications and heart and cerebrovascular diseases, thus representing high medical and socioeconomic costs. ${ }^{3-4}$

With implementation of the Family Health Strategy (FHS) of the Unified Health System (Sistema Unico de Saúde, the Brazilian public health system), patients with hypertension have increasingly been targeted by health promotion activities. However, one of the main problems that primary health care professionals experience in working with these patients is non-adherence to antihypertensive therapy. Among the factors influencing adherence/non-adherence to treatment, the family appears to have a important role in supporting its members in situations of illness, understanding lifestyle changes related to the chronic condition, making necessary adjustments, and providing support for its sick member..$^{5-6}$

The structured family context, therefore, is significantly associated with self-care behavior in CD patients, as it exercises an important role in the entire process of the individual's relationship with their disease, their treatment and adaptation to a new life style. ${ }^{6-7}$ Therefore, today the household is viewed as a space where patients with CDs can have good quality of life and maintain stability of the illness, through understanding and assistance from family members to maintain a healthy lifestyle, ${ }^{8}$ constituted by regular physical exercise, weight control, healthy diet, moderate alcohol consumption, tobacco use cessation and stress management. ${ }^{4}$
Thus, FHS nurses must receive proper training and build awareness to work with families of CD patients, because advanced professional practice is based on the professional's way of thinking, the language s/he uses, questions that $\mathrm{s} /$ he formulates and the relationships that $\mathrm{s} /$ he values. Furthermore, nurses should share responsibility for the patient's health care, by involving family members in the health-disease process, and teaching them basic care essentials to living in a household with a chronic disease. ${ }^{9}$

By collecting information regarding the family's role in adherence/non-adherence to medication and non-medication treatments of patients with SAH the nursing team is able to develop more effective intervention strategies to integrate family members into the home care process. Thus, in order increase knowledge, this study aimed to understand how patients with SAH perceive the influence of the family on their adherence/nonadherence to treatment.

\section{METHODOLOGY}

This descriptive, qualitative study was conducted with 18 SAH patients following pharmacological treatment for at least one year, and registered in the System for Registration and Monitoring of Hypertensive and Diabetic Patients (SRMHDP), in Maringá, state of Paraná, Brazil. This study is part of a matrix quantitative study, in which contact with respondents was made based on a list provided by the Municipal Health Department of Maringá, containing the names of individuals with SAH registered in the SRMHDP. During application of the instrument structured on factors possibly associated with non-adherence to antihypertensive drug treatment, those study participants who mentioned the family, either as a facilitating or hindering influence on treatment adherence, were asked to answer the following guiding question: What role does your family have in your treatment? The data collection was continued until answers started to become repetitive, and the research objectives had been attained.

Data collection took place in patients' homes in January and February 2012, using a semistructured interview that was recorded and later transcribed in full. The data were subjected to thematic content analysis, ${ }^{10}$ following pre-established steps that included pre-analysis, exploration of the material and processing of data. The pre-analysis entailed the organization, transcription and sepa- 
ration of empirical material, followed by an exhaustive reading of the data set to identify aspects relevant to the study objective. In the exploration of the material, classification and aggregation of data was done through a thorough reading to identify the common and specific aspects, giving rise to the previous categories. Finally, during treatment of the data, a deepening of the categories occurred through articulation of the empirical data with theoretical material, considering the research objectives and the themes that emerged.

The study was conducted in accordance with the guidelines governed by Resolution 196/96 of the National Health Council (NHC), following authorization by the Municipal Health Department of Maringá, and approval by the Permanent Committee on Ethics in Research with Human Beings of the State University of Maringá (Opinion n. 631/2011). All study participants signed two copies of a Free and Informed Consent Form, and were identified with the letter $\mathrm{M}$ to indicate male, and $\mathrm{F}$ to indicate female, followed by two Arabic numerals to reference the order of the interview and participant age, for example: M01, 72 years.

\section{RESULTS AND DISCUSSION}

\section{Patient characterization}

The 18 patients in the study were aged between 34 and 86 years, with a mean of 60.1 years. They were distributed equally by gender, and classified ethnically as follows: 11 Caucasian, six African or mixed-race, and one of Asian descent. The majority did not complete secondary education (13) and were employed (14). The mean family income was twice the minimum wage.

Regarding health history, 15 study participants had comorbidities, especially Diabetes Mellitus (six), inflammatory-rheumatic problems (six) and cardiovascular problems (three). The time since diagnosis of SAH ranged from one to 30 years, with a mean of 11.9 years. Regarding household, eight participants lived with their spouse only, seven lived with their spouse and children, and three lived with extended family (sons, daughters and grandchildren).

The following categories emerged from qualitative analysis of the data: a) family support as facilitator of treatment: 'my family helps me a lot!'; b) self-responsibility for treatment of the disease: 'I don't need help'; and c) lack of family support, consisting of two subcategories: 'sometimes my family gets in the way,' and 'I miss having help', which will be described below.

\section{Family support as facilitator of treatment: 'my family helps me a lot!'}

In this category it was clearly shown that the family is an important ally in treatment of SAH, being perceived by many respondents as a facilitator of treatment adherence and self-care practices such as physical exercise and proper diet, and accompanying patients on their therapeutic itinerary.

In the statements below, various forms of familial care provided to patients with $\mathrm{SAH}$ are observed:

[...] wow, words fail me, my family helps me a lot in my treatment! They remind me about medicines, do everything so that there is never a lack of good food for me [...] they help me in everything that they can [...]. The family is important in treatment, especially for the support they give us. This support comes first! (F1, 71 years).

my husband helps me a lot to remember things, for example, take the medicine at the right time and attend the group meeting for hypertensive patients at the health center (F10, 62 years).

Some participants revealed that the family can be a facilitator of adherence to antihypertensive treatment, by continuously participating in its activities:

my wife helps me a lot, she accompanies me to measure my blood pressure, to medical consultations and hospitalizations (M07, 71 years).

[...] my daughter and my wife help me, give advice, they go and schedule consultations, measure my blood pressure, and so I take better care of myself (M01, 72 years).

Most people suffering from chronic illness perceive the family as the primary source of support and security, to exchange love, affection, respect and value, and the family organization and interactions directly influence the success of treatment of $\mathrm{CD}$, in particular $\mathrm{SAH} .{ }^{11}$

More specifically, the form of support reported most frequently by respondents was that related to continuity of non-pharmacological treatment, for example, encouraging physical exercise:

even walking, he [husband] reminds me and says: 'Aren't you going to take a little walk today?' because he is going to work and I take the opportunity to go with him. In this part, I think the support he gives me is really important, sometimes I don't want to go because 
I'm tired, and he insists so that I get up and go work out (F10, 62 years).

The individuals in the study showed that family support to perform physical exercise is indispensable, because they felt encouraged to maintain a pillar of antihypertensive treatment, which is change in lifestyle. Alternatively, lack of encouragement and support was also instrumental, and one respondent ceased physical exercise after the death of his wife, even though he knew the benefits of this practice for his health.

My wife helped me, made the food less salty, and the doctor told us that walking was a good and cheap medication, and I always walked with her early in the morning, but now I stopped [...] (M08, 86 years).

For chronically-ill patients, the death of family members can generate feelings of loss and grief, which can greatly contribute to neglect of their health. ${ }^{11}$ It is necessary that the social support network, including the FHS staff, provide care to SAH patients in mourning, which is usually marked by imbalance and a series of difficulties felt by all family members, with a need for greater understanding and help to combat the fears and social isolation of the patient. ${ }^{12}$

Another change in the family routine perceived as valuable by individuals with $\mathrm{SAH}$ is the change in eating patterns of other family members:

because I have high blood pressure and she [wife] does not, she ends up cooking with less salt, even though she doesn't need to, she participates in my diet (M07, 71 years).

at home it's my wife who cooks, and she has pretty low blood pressure, but she makes food that is really low in salt, even though she and my daughter don't need to, and by that I feel valued, because I see that my entire family helps me (M01, 72 years).

These reports show the importance of health professionals, especially nurses, to work with families. When the closest family members understand that treatment of CD necessarily involves intervention on modifiable risk factors, such as combating improper diet and physical inactivity, they can better contribute to encourage greater adherence to treatment by their loved ones.

Thus, the findings of this research reinforce those of other studies, that the changes most commonly incorporated by relatives after diagnosis of SAH include activities such as participation in the patient's drug treatment, adaptation of the eating routine and encouragement of physical exercise, and accompanying the patient on medical consul- tations and group activities, which facilitate their adherence to the therapeutic regime. ${ }^{1}$

Thus, family support has been identified as significantly associated with self-care behavior in chronically-ill patients, and in the control of hereditary risk factors of the disease, concretely contributing to the treatment of individuals with $\mathrm{SAH} .{ }^{6,13}$ Changing habits requires engagement by everyone involved: the chronically-ill patient, their family members and other close ones, and the health care professionals responsible, for example, through the process of teaching and learning in the promotion and maintenance of health.

However, sometimes the family's resistance to changing poor habits that harm not only the health of the patient with $\mathrm{SAH}$, but that of all family members, is clearly shown in statements:

here at home, it's just me who has high blood pressure, and I make the food less salty, even though they don't need it [...]. At the meeting at the heal th care center, I learned that salt in large amounts is harmful, so I am cooking with less salt and with everyone eating it, we will have better health [...]. At first they complained a lot, but now they are accustomed to it, and don't complain anymore (F06, 59 years).

All families suffer from the changes imposed by a diagnosis of $\mathrm{CD}$, however, depending on the role of the member with SAH in the family, these changes occur to a greater or lesser extent, and are reflected in the routines of other Family members. ${ }^{1}$ Thus, health care professionals should seek family involvement in treatment, because the patient with SAH perceives the attention given by the family members as positive, and feels cared for and valued. In this context, other family members modifying their diet aids the patient's treatment of the disease.

It is interesting that family caregivers, although resistant in the beginning, also understand that by changing habits and routines, they are taking care of the family member with SAH. One study carried out in a municipality in southern Brazil, with 14 relatives of patients in different stages of SAH, showed that they perceived family participation as an important factor for successful treatment and control the of disease. ${ }^{1}$

To participate in the treatment and care of a patient with $\mathrm{SAH}$, caring, concern, diligence, willingness, attention and good treatment by relatives is needed, who by participating actively in the care, suppress the demands of treatment and perform tasks that control risk factors that trigger aggravation of the disease. ${ }^{14}$ 
In this respect, the relatives and people living closest to the participants of this study are direct providers of care, because they mobilized to facilitate adherence by their sick relative to treatment, which encouraged them to perform self-care activities:

so far, my family has helped me. One of the children is always bugging me: 'mom, you have to go to the doctor, get tested, let's go see how you are.' And then they get together, because I have seven children, a pinch on one side, nudge from the other, and they end up taking me to do these exams, every four to six months, these boys don't forget to take me for exams from head to toe! (F13, 72 years).

The family care provided to individuals with $\mathrm{SAH}$, such as that shown in the statement above, and those below, demonstrates that these individuals felt valued by the family and those people living closest to them, which tends produce good treatment results.

My daughter stayed here at home for ten days, she came from São Paulo, left her life, her family, just to accompany me (M08, 86 years).

I also have a son and friends who participate with me, a great family that helps me when I need it, any time of day or night, and are always ready to help me. So they are people who are not my blood, but family of love, because the person who has love pities the other, the suffering of others, the poor and sick, so he who has love will not let the other suffer alone, he suffers together (M07, 71 years).

Social networks that involve patients with $\mathrm{SAH}$ can be a strategy to improve their physical and psychological quality of life by contributing to their well-being and encouraging personal attitudes of self-care, which combine to monitor patients' health and decrease aggravations..$^{15}$ Thus, the participants in this study seem to experience this situation, which is very favorable because the presence of family gives the patient peace, strength and courage, and makes them feel safe and supported in living with the disease.

Research conducted at a university hospital in southern Brazil with seven patients with SAH showed that they understood care as the presence of the other, and the availability of family members to be present in the hospital environment. ${ }^{16}$ It is noteworthy that family care (with support from the health care system) associated with simple preventive and curative measures is capable of preventing or delaying the onset of chronic complications from $\mathrm{SAH}$, and the occurrence of this disease in other members of the family. ${ }^{1}$
Therefore, especially in primary health care, nurses must develop intervention strategies that involve families in care by sharing responsibility and participation in treatment decision-making, so that they become integral parts of care of their members with SAH.

Family support was also important during onset of the disease, by facilitating adherence of the patient with SAH to drug treatment, as shown by the following statement:

at first I had a really hard time getting used to the medications, and it was my wife who helped me to remember, she sometimes even brought me water and the medicine, but now I take everything correctly, it became an addiction, become routine (M03, 59 years).

Control of blood pressure significantly reduces risk of cardiovascular complications. Yet, one of the biggest challenges in combatting SAH is adherence to treatment. ${ }^{5,11}$ The narratives presented in this category show that the family can be a great ally for patients and health care services, as it facilitates adherence to antihy pertensive therapy, and is perceived by patients as a source of security, support and understanding. Thus, it is necessary that nurses in primary health care (re)cognize the strengths and weaknesses of families of SAH patients under their care, in order to plan strategies to include them in the therapeutic process.

\section{Self-responsibility for treatment of the disease: 'I don't need help'}

In this category, it was observed that for some participants, the family and its activities do not facilitate adherence to treatment.

My family doesn't have an important role in this part of the treatment, because for me, while I'm moving, walking, reaching, working and lucid, there won't be a problem. I don't need help, I take care of everything myself! (M15, 62 years).

My husband goes to work early and comes home late, so it's me who has to remember to take the medicines (F17, 57 years).

I travel a lot and it's just me to remember to take my medicines. Sometimes I spend two or three weeks away from home, and if I don't remember, who will remember for me? (M04, 36 years).

For these participants, the family did not represent a support in therapy, or facilitate adherence to antihypertensive treatment, because these patients understood that control of the disease depended on their own attitudes and behaviors. 
Perhaps this arises from the need of the patient to feel healthy, autonomous, responsible and in control of his or her treatment, and if the family actively participates in the therapy, the patient loses this sense of autonomy, and ends up distancing relatives from development and daily management of their treatment and its activities.

It is noteworthy that SAH is a silent, insidious and chronic disease, and the absence of symptoms contributes so that the individual does not feel sick, which complicates treatment adherence and distances the family from the care process. Thus, therapy is often neglected, and this not only hinders blood pressure control, but also encourages the emergence of renal complications and heart and cerebrovascular diseases.

However, inclusion of the family in caring for patients with SAH has been described as very important, and can increase control of blood pressure and prevention of complications. This is because in addition to being an integral unit of society, the family can promote the health of its members. Thus, in situations of disease, the family is responsible for continuity of care until full recovery, and when this is not possible, for living with the consequences of the chronic condition. ${ }^{17}$

For one study participant, separation from the family after being diagnosed with $\mathrm{SAH}$ and diabetes mellitus (DM) was due to his isolating and aggressive behavior, and denial of the disease, which resulted in little assistance received from his family, and complicated his treatment adherence:

I don't like to talk about my illness, because then they want to fix it and it's no use [...]. So I tell my family that they don't need to tell anyone that I'm diabetic, that I'm hypertensive. The doctor and I have to know, no one else [...]. I live a very normal life, if I want to eat olives and drink beer, I eat and drink without the slightest problem (M15, 62 years).

Despite the diagnosis of SAH and DM, M15's statement shows that he does not consider himself chronically ill. The fact that he uses the transient form of the Portuguese verb "to be" (estar) instead of the permanent form (ser) demonstrates his denial of DM as an integral part of his life, leading him to follow an inappropriate lifestyle that may result in the emergence, in the medium and long term, of complications from SAH and DM.

Non-adherence to, and disinterest in, treatment increase when there is no family involvement in the patient's daily care. Yet, the chronically-ill patient should require, or at least accept, family participation in their therapeutic regimen, oth- erwise the interpersonal relationships between the family members becomes conflictual, with a greater tendency for the SAH patient to neglect their treatment, ${ }^{11}$ as noted in the statement by M15.

On the other hand, some respondents said they did not need family support, and were afraid of the consequences of not performing the antihypertensive treatment and becoming dependent on care. In these situations, the patients believed that family help was indispensable:

with the medication I have no problems, I'm lucid and active, so I can get on by myself. I don't know if I will need help in a few years, because high blood pressure can cause problems (F02, 59 years).

my family doesn't have an important role in this part of treatment [...]. Unless I have a stroke and become disabled, then it will have a very important role, to give me baths [...] to bring me water (M04, 36 years).

These statements convey a limited view of the respondents in regard to family support in the treatment of a CD, because they believed that the family would only be important in a framework of dependency. In this perspective, one qualitative study carried out in Várzea Grande, state of Mato Grosso, with seven SAH patients, showed that the respondants emphasized the fear of suffering complications from the disease, such as cerebrovascular accident or myocardial infarction, which encouraged them to use medications for prevention. ${ }^{18}$

One study conducted in Fortaleza, in the state of Ceará, with 13 nurses from the FHS, evaluated how nursing consultations were conducted with SAH patients, and showed that the nurses considered family presence in patient monitoring to be essential, because they believed that this could encourage treatment adherence. The nurses also reported also that the lifestyle changes of the patient require intense participation of the family, because these changes affect all of its members. ${ }^{19}$

Therefore, it is necessary for health care professionals to work with patients who perceive themselves to be self-sufficient in the treatment, in order to show them how much family participation can help them in adverse situations from the disease and treatment. It is also imperative that health care professionals stimulate family participation in the development and monitoring of therapies for SAH patients, as these integrate a family and social context, with commitments and life plans, and are affected by a CD. Therefore, it is necessary to know the meaning of the illness for the patient, and find alternatives that encourage adaptation by them and their family to the new reality. 


\section{Lack of family support}

This category, composed of two subcategories, found that some respondents did not receive as much family support as they wanted; however, this absence was not the result of their denial of the disease or withdrawal from the family, but rather due to aggressive behavior or lack of knowledge regarding the disease among the family.

\section{'Sometimes my family gets in the way'}

Stressful situations and worry for family members can aggravate high blood pressure, as they are constant sources of anxiety and stress for individuals with SAH: sometimes family gets in the way, because people who have a lot of family end up getting grouchy and irritated. My husband is angry, it's bad [...] I could control my blood pressure better if he didn't bother me so much, but because of disagreements with the children, he takes everything out on me (F16, 61 years).

my family isn't very important in my treatment [...] the only thing they can do is try to make me calmer, but lately they haven't even been doing that (M18, 53 years).

As shown in the statements above and reinforced by literature, repeated experience of stressful situations within the family can lead SAH patients to reduce self-care and lose control of the disease, and thus deterioration of their health. ${ }^{11}$ Multidisciplinary health care teams must be aware of the recurrence of stressful situations, with a view toward taking earliest action possible.

One study in a city in southern Brazil with 20 SAH patients showed that affective, informative and socializing family support, and interactions among family members, directly influenced the success of treatment of the disease. ${ }^{15}$ This fact can also be observed in the present study, as conflictual family relationships were described as hindering control of blood pressure.

\section{'I miss having help'}

Failure to follow an appropriate diet by the entire family was reported by some respondents as hindering adherence to non-pharmacological treatment of SAH: when I make food with little salt, my husband complains that the food is bland, so then I say 'if you want more salt, add more salt,' but this situation bothers me, because he knows I don't cook without salt because I want to (F17, 57 years).

F17's remark makes it clear that lack of family support in adapting eating habits leads her to feeling depressed, which may encourage nonadherence to treatment. Thus, SAH stands out in the family context as an experience that is difficult to adapt to, because its control requires behavior changes to eating habits and lifestyle, not only for the hypertensive person, but the entire family. ${ }^{6}$ If there is no understanding and involvement with these changes by all members of the family, living with the disease and adhering to the treatment regimen become more difficult.

One of the respondents acknowledges that the family is important in treating patients with $\mathrm{SAH}$; however, due to her own family's lack of knowledge regarding the disease, she did not receive support for her therapy:

my family doesn't help me because they think I'm being fussy; my husband doesn't understand that it's a disease. I say I can't get nervous, because my blood pressure will rise, and he doesn't really care. He doesn't help me to buy the medicine, doesn't help me remember to take the medication, or accompany me to consultations (F05, 34 years).

Due to her family's lack of knowledge regarding the disease, its symptoms and treatment, F05 had difficulty following her treatment regimen:

in my house, we both cook. I make the food without salt, but when he [husband] cooks, he adds too much [...] I have already explained to him why hypertensive people can't eat salt, but it's hard for him to understand and help me. [...]. I have asked him several times to help me to remember to take the medicines every day, at the right times, but he doesn't remember. I think if my husband understood more about the disease, the symptoms, the negative impacts it can have, his support would be essential in my treatment, the family can always help (F05, 34).

It is perceived in the statement above that the family's knowledge regarding the disease and treatment was incipient. This reflects an important failure of health care professionals working in the FHS, particularly nurses, which are the strongest link between users and the health care services, because they should seek to incorporate close relatives into the treatment of SAH patients, to encourage their adherence to therapy. It is essential that family participation in treatment is understood by health care professionals as a factor that increases treatment adherence.

The biggest obstacle in controlling SAH remains non-adherence to therapy, which explains why it is regarded as a public health problem. The factors knowledge and adaptation, both for SAH 
patients and their families, are still accuntable for the enormous resistance to adherence to antihypertensive treatment that professionals encounter. While studies and investment by the Ministry of Health are important, the solution to the problem is to overcome the challenge of engaging both patients with SAH and their families in treatment. ${ }^{14}$

One study carried out in Fortaleza with 400 relatives of patients enrolled in an $\mathrm{SAH}$ alliance showed that the families' knowledge of the disease, although incipient, was essential to the viability of antihypertensive treatment. The referred study emphasized the importance of nurses to empower the family, offer support and technicalscientific knowledge, so that relatives know how to deal with the disease, and can experience its most complex moments in a healthy manner, which, in turn, has a positive influence on continuity of the therapeutic regime. ${ }^{6}$

The findings indicate that the family can be both an important network of support that can either facilitate or hinder adherence to treatment of SAH. Therefore, health care education actions should target families of SAH patients, and not be restricted to the sick individual.

\section{CONCLUSION}

The results of this study demonstrated that for most respondents, family support plays an important role in antihypertensive therapy, by encouraging the adoption of self-care practices such as physical exercise and proper diet, and accompanying their therapy. Thus, it was described as a facilitating agent of adherence to treatment.

On the other hand, some participants reported that the family is not a link to support treatment, either because they believed that control of the disease depended exclusively on their own attitudes and behaviors, or because they did not receive as much family support as they desired. However, it is believed that family involvement in home care of SAH patients may be a factor that encourages blood pressure control and prevention of complications. Thus, the findings of this study can help FHS nurses to reformulate educational activities developed with SAH patients. For example, nurses may be able to develop intervention strategies in monitoring these patients, including the family as the unit of care, and share responsibility with the family for activities that involve selection and adherence to therapy.

\section{REFERENCES}

1. Lopes MCL, Marcon SS. A hipertensão arterial e a família: a necessidade do cuidado familiar. Rev Esc Enferm USP. 2009 Abr-Jun; 43(2):343-50.

2. Martins JJ, Albuquerque GL, Nascimento ERP, Barra DCC, Souza WGA, Pacheco WNS. Necessidades de educação em saúde dos cuidadores de pessoas idosas no domicílio. Texto Contexto Enferm. 2007 Abr-Jun; 16(2):254-62.

3. Miranzi SSC, Ferreira FS, Iwamoto HH, Pereira GA, Miranzi MAS. Qualidade de vida de indivíduos com Diabetes Mellitus e hipertensão acompanhados por uma equipe da saúde da familia. Texto Contexto Enferm. 2008 Out-Dez;17(4):672-9.

4. Sociedade Brasileira de Cardiologia, Sociedade Brasileira de Hipertensão, Sociedade Brasileira de Nefrologia. VI Diretrizes brasileiras de Hipertensão. Arq Bras Cardiol. 2010; 95(Supl. 1):1-51.

5. Santos JC, Florêncio RS, Oliveira CJ, Moreira TMM. Adesão do idoso ao tratamento para hipertensão arterial e intervenções de enfermagem. Rev Rene. 2012 Abr-Jun; 13(2):343-53.

6. Saraiva KRO, Santos ZMSA, Landim FLP, Teixeira AC. Saber do familiar na adesão da pessoa hipertensa ao tratamento: análise com base na educação popular em saúde. Texto Contexto Enferm. 2007 Abr-Jun; 16(2):263-70.

7. Brito DCS. Cuidando de quem cuida: estudo de caso sobre o cuidador principal de um portador de insuficiência renal crônica. Psicol Estud. 2009 JulSet; 14(3):603-7.

8. Silveira CL, Budó MLD, Silva FM, Beuter M, Schimith MD. Rede social das cuidadoras de familiares com doença crônica incapacitante no domicílio: implicações para a enfermagem. Cienc Cuid Saúde. 2009 Out-Dez; 8(4):667-74.

9. Elsen I, Souza AIJ, Prospero ENS, Barcellos WBE. $\mathrm{O}$ cuidado profissional às famílias que vivenciam a doença crônica em seu cotidiano. Cienc Cuid Saúde. 2009; 8(Supl): 11-22.

10. Bardin L. Análise de conteúdo. Lisboa (PT): Edições 70. 2008.

11. Costa RS, Nogueira LT. Contribuição familiar no controle da hipertensão arterial. Rev Latino-Am Enfermagem. 2008 Set-Out; 16(5):871-6.

12. Barreto MS, Silva RLDT, Waidman MAP, Marcon SS. Percepção da família sobre a assistência a pessoas com hipertensão arterial que foram a óbito. Rev. Eletr. Enf. [online]. 2013 Jan-Mar [acesso 2013 maio 28]; 15(1):162-71. Disponível em: http://www.fen. ufg.br/fen_revista/v15/n1/pdf/v15n1a19.pdf

13. Lopes MCL, Carreira L, Marcon SS, Souza AC, Waidman MAP. O autocuidado em indivíduos com hipertensão arterial: um estudo bibliográfico. Rev Eletr Enferm [online]. 2008 Jan-Mar [acesso 2012 Out 
01];10(1):198-211. Disponível em: http:/ / www.fen. ufg.br/revista/v10/n1/v10n1a18.htm

14. Saraiva K, Santos ZMSA, Lima HP, Sena VL. O processo de viver do familiar cuidador na adesão do usuário hipertenso ao tratamento. Texto Contexto Enferm. 2007 Jan-Mar; 16(1):63-70.

15. Faquinello P, Marcon SS, Waidmann MAP. A rede social como estratégia de apoio a saúde do hipertenso. Rev Bras Enferm. 2011 Set-Out; 64(5):849-56.

16. Costa VT, Alves PC, Lunardi VL. Vivendo uma doença crônica e falando sobre ser cuidado. Rev Enferm UERJ. 2006 Jan-Mar; 14(1):27-31.

17. Lopes MCL; Marcon SS. Concepts of health and sickness in families living with arterial hypertension: a qualitative study. Online Braz J Nurs [online]. 2009 [acesso 2012 Out 10]; 8(3). Disponível em: http:/ / www.objnursing.uff.br/index.php/nursing/ article/view/j.16764285.2009.2484/544

18. Zagui IC, Borges SR, Pereira JG, Pegoraro VA, Duarte SJH. Percepção das dificuldades relacionadas ao tratamento entre pessoas com hipertensão arterial sistêmica. Rev Eletr Gestao \& Saude. 2011 Jan-Abr [acesso 2013 Mai 30]; 2(1):341-53. Disponível em: http://www.gestaoesaúde.unb.br/index.php/ gestaoesaúde/article/view/113/pdf

19. Felipe GF, Abreu RNDC, Moreira TMM. Aspectos contemplados na consulta de enfermagem ao paciente com hipertensão atendido no Programa Saúde da Família. Rev Esc Enferm USP 2008 OutDez; 42(4):620-7. 